\title{
A Case discussion on Dushta Vrana (Chronic Wound)
}

\section{Case report}

\author{
Vijakumar $\mathbf{B}^{1^{*}}$, Prasanna $\mathbf{N ~ R a o}^{2}$, Hemantkumar $\mathbf{P}^{3}$ \\ 1*. Asst. Professor N.K.J.A.M.C. Bidar - Karnataka. \\ 2. Principal, 3. H.O.D Dept. of Shalya tantra, \\ S.D.M.College of Ayurveda, Hassan, Karnataka, India
}

\begin{abstract}
The healing of wound or an ulcer is the natural response of the body. Naturally wound will heal in one week if no doshic invasion or infection takes place. The vrana more than a week called dushta vrana which fail to heal for a long period and result into chronic wound (dheergha kalanubandhi dushta vrana), such vrana needs shodhana (Abhyantara) and ropana (Bahya) chikitsa. Virechana and Jatyadi ghruta application is the best line of management for vata-pitta pradushtaja dushta vrana. A case report of 50 year - old men, who presented with complaints of an open ulcer on the dorsum of the right foot associated with pain, discharge, slough, foul smell, oedema and discolouration of the skin has been presented here.
\end{abstract}

Keywords: Dushta vrana, Shodhana, Ropana, Virechana, Jatyadi ghruta.

\section{Introduction:}

As the sciences have advanced, newer remedies are tried out for speedy recovery, but the oldest remedies still lead the race. Wound healing procedures described by sushruta still holds its place today. The faster the wound healing, the faster is the recovery of the patient enabling him to resume his daily routine. These included various purification therapies (shodhana) and local applications (ropana) of natural resources, which are available very easily and heal the wound faster without any sepsis.

One of such purification therapy explained by sushruta is virechana to eliminate the pravrudha doshas out from the body, particularly in vata-pitta praduhtaja dushta vrana. Jatyadi ghruta is

*Corresponding Author:

Vijaykumar B

Asst. Professor

N.K.J.A.M.C. Bidar

Karnataka, India

E-mail: drvijugtri.com@rediffmail.com

Mob. No: 09845724774 used as an external application in combination with virechana.

\section{Case report:}

A 50 yr old male presented with the complaint of an ulcer on the dorsum of the right foot, associated with pain, discharge, slough, foul smell, oedema and discoloration of the skin near by the ulcer since three months. Three months back patient was alright, then while working in the field a stone slips from his hand and fell down on his right foot, produced swelling with pain. After few days the swelling burst due to cellulitis and suppuration and resulted into wound. Wound was treated with conventional antibiotic ointment by a local doctor but the wound failed to respond, presumably because of wound contamination and movement of the part. Treatment continued for a period of about three months, but the wound became worst, so he visited us. There is no history of DM, HTN and on local examination there is no varicosity in the affected limb. 
The family history was not suggestive of anything specific. The local examination revealed an open oval shaped ulcer on the dorsum of the right foot (approximately $6 \times 4 \mathrm{~cm}$ ) associated with pain, discharge etc. There was tenderness near by the lesion with elevated local temperature and surrounding indurations.

The classical lakshanas of dushta vrana such as durgandhata, pooti puya sraava, vedana etc were observed.(1) The adhisthana was mamsa with vata-pitta predominance. Routine heametalogy $(\mathrm{Hb}$, TC, DC, ESR, RBS) and urine investigations were within normal limits. As Susrutha has describe the sixty manifold measures (shasti vrana upokarmas) for a wound management from its manifestation to the normal rehabilitation of the hair in the scar. And given foremost to, measures like shodhana and ropana in the management of dusthavrana. Shodhana comprises two varieties of purification.

- Internal purification (Antargata shodhana)

- External purification (Bahirgata shodhana)

As the experts of the wounds recommend virechana in wounds vitiated by predominant vata and pitta dosha and which are chronic (2). So here virechana therapy selected to elimate these pravruddha doshas out from the body and jatyadi ghrita was applied to dusthavrana. The details of the virechana procedure are explained in table-1.

Table 1: Procedure administered to the patient

\begin{tabular}{|c|c|c|c|}
\hline Procedure & Medication & Dose & Duration \\
\hline $\begin{array}{l}\text { Deepana } \\
\text { Aushadhi(Appetizer) }\end{array}$ & Panchacola Phanta & $\begin{array}{ll}50 & \mathrm{ml} \\
\text { twice/day }\end{array}$ & 2 days \\
\hline $\begin{array}{l}\text { Snehapana(drinking medicated } \\
\text { ghee) }\end{array}$ & $\begin{array}{l}\text { Panchatikta } \\
\text { Guggulu Ghrita } \\
\text { daily morning at } \\
\text { 8am }\end{array}$ & $\begin{array}{l}\text { Day } 1=30 \mathrm{ml} \\
\text { Day } 2=60 \mathrm{ml} \\
\text { Day } 3=90 \mathrm{ml} \\
\text { Day } 4=120 \mathrm{ml} \\
\text { Day } 5=150 \mathrm{ml}\end{array}$ & 5 days \\
\hline $\begin{array}{l}\text { (a)Sarvanga Abhyanga(whole body } \\
\text { oil massage) and (b)Sarvanga } \\
\text { Bashpa Swedana } \\
\text { therapy) }\end{array}$ & Murchita taila & Day 6, 7 and 8 & 3 days \\
\hline $\begin{array}{l}\text { Pradhana Karma (Main } \\
\text { Procedure) } \\
\text { Virechana (Purgation therapy) }\end{array}$ & $\begin{array}{l}\text { Trivrutta leha was } \\
\text { given in the morning } \\
\text { by } 8 \text { am on the day } \\
8^{\text {th }}\end{array}$ & $\begin{array}{l}50 \mathrm{gm} \text { with } \\
100 \mathrm{ml} \mathrm{milk}\end{array}$ & 1 day \\
\hline $\begin{array}{l}\text { Pashchatkarma (postprocedure) } \\
\text { Samsarjana Karma }\end{array}$ & Rice gruel & $\begin{array}{l}\text { One glass on } \\
\text { the day } 9 \text { Day } \\
10 \text { and } 11\end{array}$ & $\begin{array}{l}1^{\text {st }} \text { day (when } \\
\text { ever hungry) } \\
2^{\text {nd }} \text { and } 3^{\text {rd }} \text { day }\end{array}$ \\
\hline
\end{tabular}

Locally every morning the wound was cleaned with lukewarm water. After cleaning, jatyadi ghuta was applied in adequate quantity with the help of the spatula and the wound was covered with sterile gauze and loosely bandage.

\section{Results:}

The clinical features of dushta vrana were improved at the end of second week and the wound was healed completely at the end of $4^{\text {th }}$ week leaving only a minimal 
scar Fig 6. With a follow up for a period of one year, the patient has shown no signs of

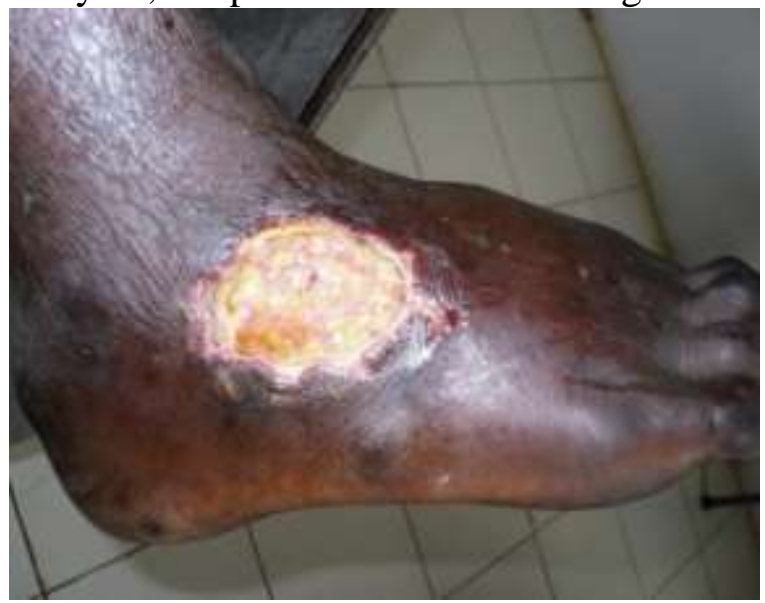

Fig.1.Before treatment

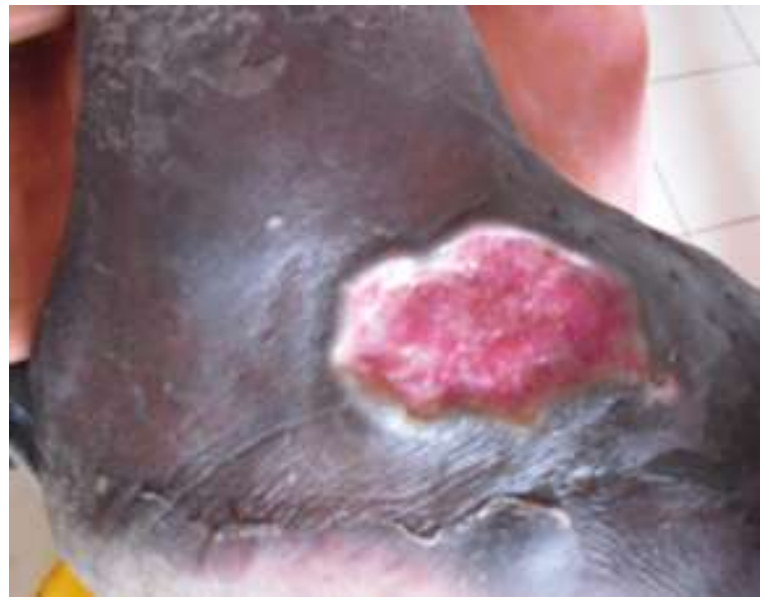

Fig.3.During treatment

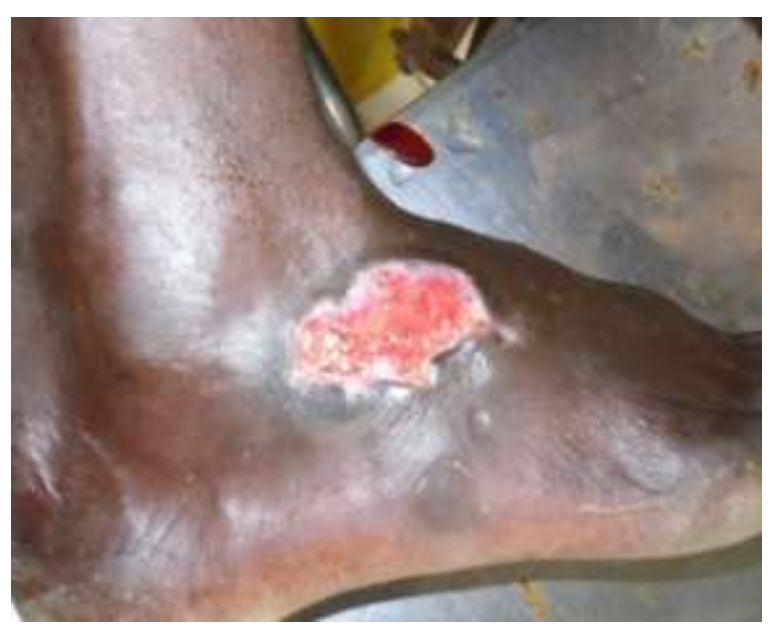

recurrence.

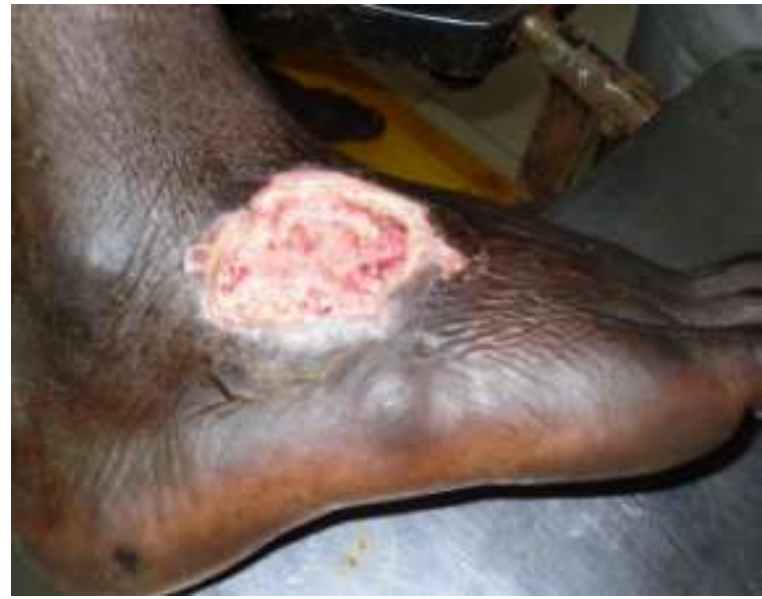

Fig.2.During treatment

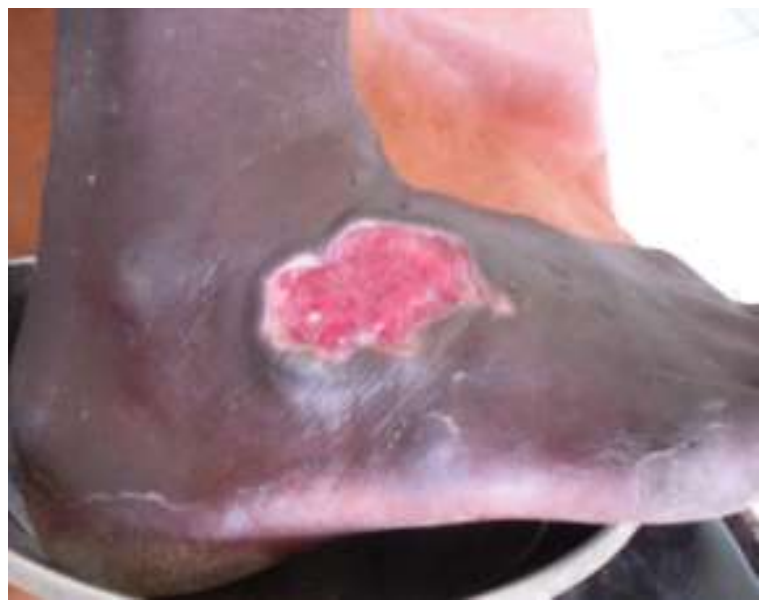

Fig.4.During treatment

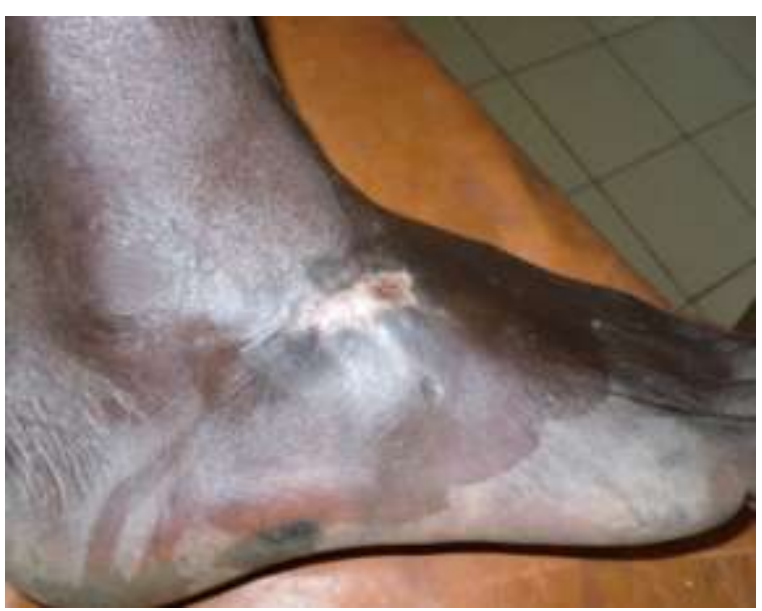


Fig.6.After treatment

\section{DISCUSSION ON EFFECT OF TREATMENT:}

- Effect of treatment on varna: Change in colour occured when dushta vrana get converted into shuddha, which was due to elimination of doshas out from the body.

- Effect of treatment on sraava: The vitiated pitta is responsible for paka kriya, which by bitiating the rakta forms pooya. The virechana karma helps in elimination of vitiated pitta from the body and thus controls upon the paka kriya, which results in the subsidence of sraava. Absence of sraava(pus) suggestive of the wound is devoid of infection.

- Effect of treatment on vedana: Vedana pradurabhava in dushta vrana is the effect of vitiated vata and pitta dosha on the dhatus like rasa, rakta, mamsa etc. Virechana controls the vitiated vata and pitta. Thus virechana therapy not only expels the vitiated pitta dosha but also controls the vitiated the vata dosha by removing margaavarodha.

- Effect of treatment on Granulation tissue: Virechana not only eliminates the doshas but also helps in removing the impurities of jeeva shonita, dhatus, indriyas and oja, which results in formation of healthy granulation tissue.

- Effect of treatment on Size of the wound: The virechana undertaken has helped for proper perfusion (Circulation) to the wound and hence accelerated the wound healing process. Thus it resulted in the reduction of size of the dushta vrana.
Mode Action of Virechana

Virechana Dravya eliminates Doshas due to

$\begin{array}{lll}\text { Saratva } & - & \text { Mobility } \\ \text { Sukshma } & - & \text { Minuteness } \\ \text { Tikshna } & & - \\ \text { Sharpness } & & \\ \text { Ushna } & - & \text { Hotness } \\ \text { Vikasi } & - & \text { Loosening }\end{array}$

(dispersibility)

\section{Action of Gunas (Dalhana)}

Saratva Guna
Anulomana of Dosha's
Sukshma Guna - Does
all minute channels of the body
Tikshna Guna - Brings the
Dosha's to the Koshta
Ushna Guna
Vilayana (Softening of abstracted
Dosha's) Does
Vikashi Guna - Does the
Dhatu Shaithilyakarana.(3)

On the basis of above refrence the probable mode of action described as follow:

The sneha GTG (Guggulu Tikta Ghrita) used for the Dosha Utklesha purpose, is of lipid binded protein mixed with medicaments enter the cells and get mix up with toxins and waste products of metabolism.

Then the purgative drug is given (Trivrit Lehya) in empty stomach when pyloric end is open. The drug passes quickly to the intestine, where while passing through it, produces mild inflammation in it, which increases the permeability of vessels of the intestine. Due to this the Vyavayi, Vikasi and Sookshma properties of Trivrit Lehya quickly reach up to cellular level where the nexus of toxins with tissues exists. In order to break down the complicated nexus, the 
Ushna property of drug soften the chemical bonds of the toxins. There after they are broken down by Teekshna property, in to smaller and relatively less harmful molecules which can be removed out of the cell. Thus released toxins and waste products of metabolism are brought to the intestine, where due to purgation action they are thrown out of the body.

So the Snehapana Dravya (GTG) and Trivrit Lehya are having target oriented activity, which target the cells and cleans the body. And also increases sensitivity of cells in the ulcer (Dushtavrana) sites towards the local application (Jatyadi Ghrita) and hence accelerates the wound healing process.

- The treatment of virechana along with local application of jatyadi ghruta resulted marked improvement in varna, vedana, sraava, size of the wound and granulation tissue.

\section{Conclusion:}

- Virechana acts through systemic correction and regulation of Doshas, which involves in the formation of Dushtavrana.

- Virechana improves potency of individual cell of the body, increases sensitivity of cells in the ulcer site towards the local application i.e. Jatyadi Ghrita and hence accelerates the wound healing. It has fast wound healing property.

- The combination of sodhana (Virechana) and ropana (jatyadi ghrita) resulted in proper and early healing of the dushta vrana.

\section{Refrences:}

1. Vaidya Yadavji Trikamji acharya: Sushruta samhitha with Dalhanacharya Nibhandha sangraha and Gayadasacharya Nyaychandrika Panjika commentary edited by Krishnadas Academy, Varanasi, Edition reprint in 1998. Sutrasthana 22:7 pp 108.

2. Vaidya Yadavji Trikamji acharya,; Sushruta samhitha with Dalhanacharya Nibhandha sangraha and Gayadasacharya Nyaychandrika Panjika commentary edited by Krishnadas Academy, Varanasi, Edition reprint in 1998. Chikitsa Sthana 1:32 pp 400

3. Vaidya Yadavji Trikamji acharya,; Sushruta samhitha with Dalhanacharya Nibhandha sangraha and Gayadasacharya Nyaychandrika Panjika commentary edited by Krishnadas Academy, Varanasi, Edition reprint in 1998. Chikitsa Sthana 33:33 PP519. 